\title{
Calibration of the Benthic Foraminiferal Oxygen Index in the Marmara Sea
}

\author{
Michael A. KAMINSKI
}

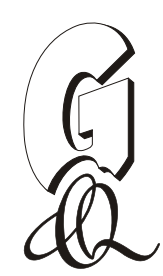
Kaminski M.A. (2012) - Calibration of the Benthic Foraminiferal Oxygen Index in the Marmara Sea. Geol. Quart., 56 (4): 757-764, doi:
10.7306/gq.1061

\begin{abstract}
Benthic foraminifera (total assemblages) were studied from 30 sea-floor samples collected along a bathymetric transect on the southern shelf of the Marmara Sea from depths of 15-350 m. At each station, Kaiho's Benthic Foraminiferal Oxygen Index (BFOI) was calculated based on species abundances using the methods outlined by Kaiho (1994). The calculated BFOI values were converted to analogue oxygen values, and calibrated to the dissolved oxygen values measured $1 \mathrm{~m}$ above the sea-floor at each station. In the surface waters and central part of the Marmara Shelf transect, the BFOI values reproduce the measured dissolved oxygen values with a remarkable degree of accuracy. Beneath the pycnocline at depths of 30 to $75 \mathrm{~m}$, the BFOI underestimated the measured oxygen values. This discrepancy is attributed to seasonally higher summer oxygen values within the chlorophyll maximum, corresponding to the position of the Mediterranean Inflow Water (MIW) present during summer. In the deeper part of the transect (below $140 \mathrm{~m}$ ), BFOI values overestimated the measured oxygen values. This discrepancy is attributed to the presence of denser MIW that cascades down the submarine canyon beneath the Marmara ship channel during winter, ventilating the deep Marmara Sea. The BFOI accurately points out the seasonal differences in the position and depth of the MIW in the southwestern Marmara Sea. The BFOI likely reflects the longer-term oxygen values averaged over the span of many years.
\end{abstract}

Michael A. Kaminski, Earth Sciences Department, King Fahd University of Petroleum and Minerals, PO Box 701, Dhahran, 31261 , Saudi Arabia; Department of Earth Sciences, University College London, Gower Street, London, WC1E 6BT, U.K., e-mail. kaminski@kfupm.edu.sa (received: October 4, 2012; accepted: October 16, 2012; first published online: October 22, 2012).

Key words: foraminifera, oxygen, ecology, Benthic Foraminiferal Oxygen Index (BFOI), Marmara Sea.

\section{INTRODUCTION}

The Marmara Sea is a small, but deep marine basin that links the eastern Mediterranean with the Black Sea. Surface waters in the Marmara Sea are dominated by outflowing brackish waters originating from the Black Sea, while the highly saline deep-water of the Marmara Sea is of Mediterranean origin. The strong halocline present at around $30 \mathrm{~m}$ depth prevents the mixing of these two water masses, and consequently the deepwaters of the Marmara Sea become dysoxic, with dissolved oxygen values typically below $1.5 \mathrm{ml} / \mathrm{l}$ (Alavi, 1988). A bathymetrical transect on the Marmara Sea shelf therefore intersects water masses that exhibit a strong gradient in dissolved oxygen content.

As part of a larger initiative to study the foraminiferal assemblages of the Marmara Sea and the history of marine connections with the Mediterranean (Aksu et al., 2002a, b; Kaminski et al., 2002) we collected a depth transect of grab samples on the southern shelf of the Marmara Sea. The area was selected be- cause this sector of the Marmara Sea was deemed to be sufficiently far from industrial centres and shipping lanes that the sea-floor is likely to be relatively unaffected by human activities. Previous studies in the area have concentrated solely on the distribution of the benthic foraminiferal taxa (e.g., Chendeş et al., 2004; Avşar et al., 2006; Phipps et al., 2010; Frontalini et al., 2011), and compared the major foraminiferal assemblages to the water masses present in the area. The aim of this study is to analyse the foraminiferal data published previously (Phipps et al., 2010) to calculate Kaiho's Benthic Foraminiferal Oxygen Index (BFOI; Kaiho, 1991, 1994, 1999) and calibrate the index values to the dissolved oxygen contents measured in bottom waters at the same sample stations.

The BFOI is a powerful tool for interpreting changes in bottom water oxygenation in the geological past (Kaiho, 1991). The first direct calibration of the BFOI to measured dissolved oxygen values was published by Kaiho (1994), but all of the stations with low oxygen values in his study were from the margins of the Pacific Ocean. Because of the lack of direct calibration of the BFOI to bottom water oxygen values in the Atlan- 
tic-Mediterranean region, some authors working with the eastern Mediterranean sapropels have avoided the use of the BFOI for interpreting past oxygen values (e.g., Abu-Zied et al., 2008). Others (e.g., Morigi, 2009) have used the BFOI to interpret changes in oxygenation across Sapropel S5 in the Mediterranean, but with the caveat that the index has not been calibrated to modern faunas. Since the observed oxygen values in the Marmara Sea are well within the range of dissolved oxygen values that Kaiho (1994) used to originally calibrate his index, I believed that this proxy could be independently calibrated and applied in the eastern Mediterranean area. By calibrating this proxy to the modern dissolved oxygen values in the study area, it should be possible to better interpret the Quaternary palaeoceanography of deep-water masses in the Marmara Sea and adjacent areas.

\section{STUDY AREA}

The Marmara Sea lies in a transtensional basin situated along a set of an echelon dextral strike-slip faults that form part of the North Anatolian Transform Fault system (Aksu et al., 2000). Two relatively shallow and narrow straits known as the Dardanelles and the Bosphorus link the Marmara Sea with the Aegean Sea to the west and the Black Sea to the north-east respectively and serve as the only connections between the Black Sea and the Mediterranean (Fig. 1). Although the Dardanelles Strait reaches depths of 100-110 m, there are several sills with contemporary depths of $60-70 \mathrm{~m}$; as a result these sills prevent the transfer of deep-water between the Aegean Sea, Marmara Sea and Black Sea (Ergin et al., 1997). At present, brackish surface water from the Black Sea outflows into the Marmara Sea through the Bosphorus Strait, while saline deeper water from the Marmara Sea flows northwards as a countercurrent. This two way flow is repeated in the Dardanelles Strait, thereby creating an overall estuarine circulation within the Marmara Sea.

Due to the strong outflow of brackish Black Sea waters, a strong halocline is present throughout the Marmara Sea, generating low-oxygen and stratified conditions below a thin, well-mixed and more highly oxygenated surface layer.

\section{METHODS}

Samples acquired for micropalaeontological analysis were collected on board the R/V Koca Piri Reis of the Institute of Marine Sciences and Technology, Dokuz Eyl 1 University, Izmir, Turkey during Cruise MAR-02 in August 2002. During the MAR-02 cruise sea-floor sediments were collected at 30 stations using a Shipeck grab sampling device along a depth transect extending from 15 to $350 \mathrm{~m}$ water depth.

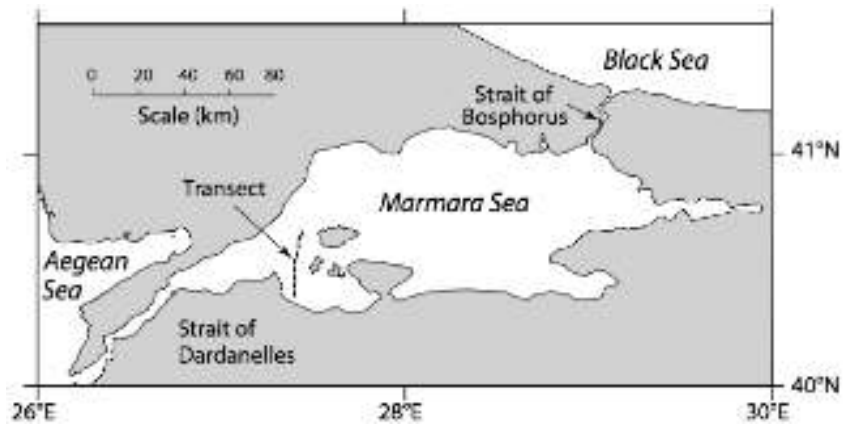

Fig. 1. Location of the Marmara Sea, with the Dardanelles and Bosphorus straits indicated, modified from Aksu et al. (2002)

The locations of samples taken along the transect are shown in Figure 2. Surface sediment was scraped from the surface of the recovered grab sample with a spatula, immediately washed on board ship through a $63 \mu \mathrm{m}$ sieve, and the sand fraction preserved in ethanol with Rose Bengal stain. Samples were subsequently washed over a $63 \mu \mathrm{m}$ sieve again to remove the excess stain, dried, and split into aliquots using a modified Otto microsplitter. Benthic foraminifera were picked from the $>25 \mu \mathrm{m}$ fraction and mounted onto cardboard reference slides for counting by Chendeş et al. (2004). In this study, all calcareous benthic foraminiferal specimens mounted on the reference slides were identified using taxonomical studies by Parker (1958), Yanko and Troitskaya (1987), Cimerman and Langer (1991), Sgarrella and Moncharmont Zei (1993), and Rasmussen (2005).

Environmental parameters such as water depth (m), temperature $\left({ }^{\circ} \mathrm{C}\right)$, salinity $(\mathrm{g} / \mathrm{L})$, and dissolved oxygen $(\mathrm{ml} / \mathrm{l})$ were measured in situ at 1 metre intervals in vertical profile at each station. Standard CTD profiles were obtained at each station using a $S B E-911 \mathrm{CTD}$, equipped with pressure, temperature and conductivity sensors. The accuracy, measurement range,

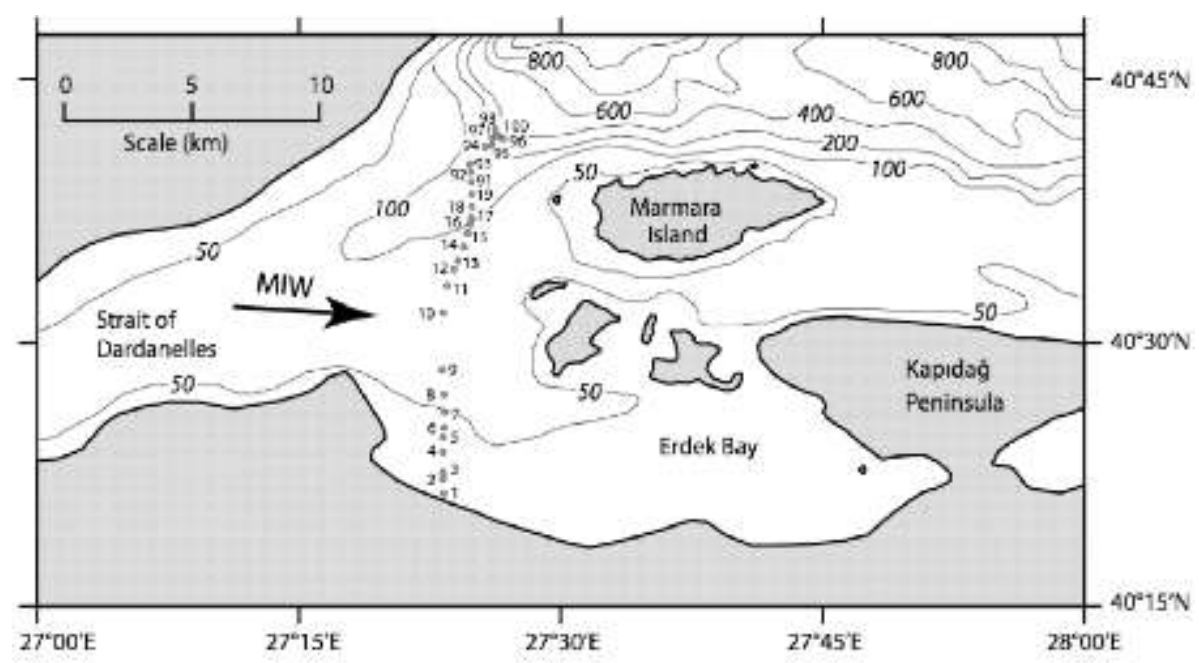

Fig. 2. Simplified map of the southwestern Marmara Sea shelf, showing the location of sampled transect stations

The $100 \mathrm{~m}$ contour in the northern part of the sample transect outlines the location of the submarine canyon beneath the Marmara Ship Channel. The arrow indicates the approximate location of the axis of the subsurface Mediterranean Inflow Water (MIW) current where it impinges on the sea-floor, as observed in during the MAR-02 cruise in summer 2002 
Properties of SBE-911 CTD system sensors

\begin{tabular}{|l|c|c|c|}
\hline \multicolumn{1}{|c|}{ Parameter } & Measurement range & Accuracy & Resolution \\
\hline Pressure $[\mathrm{psi}]$ & 0 to 3000 & $0.015 \%$ of full scale & $0.001 \%$ of full scale \\
\hline Temperature $\left[{ }^{\circ} \mathrm{C}\right]$ & -5 to +35 & \pm 0.001 & 0.0002 \\
\hline Conductivity $[\mathrm{S} / \mathrm{m}]$ & 0 to 7 & \pm 0.0003 & 0.00004 \\
\hline Dissolved oxygen $[\mathrm{ml} / \mathrm{l}]$ & 0 to 15 & \pm 0.1 & \pm 0.01 \\
\hline
\end{tabular}

and resolution of CTD sensors are given in Table 1. Sea Bird CTD sensors were calibrated by the northwest Regional Calibration Center (operating under contract to NOAA) once a year.

The well-preserved live (stained with Rose Bengal) and dead foraminiferal specimens from the samples picked by Chendeş et al. (2004) were grouped into the Oxic, Suboxic, and Dysoxic morphogroups described by Kaiho (1994), and their abundances were entered into an excel spreadsheet. A list of species and counts used in the computation of the BFOI were published in the study of Phipps et al. (2010). Fragmented tests were excluded from the counting, as these may have been transported. The list of identified species subdivided into their respective morphogroups is given in Appendix 1.

Kaiho (1994) provided two empirical equations that he used to calculate the BFOI, depending on the presence or absence of oxic species. Because at least one oxic species was found in each Marmara Sea sample, the following equation was used:

$$
\{[O /(O+D)] \times 100\}
$$

where: $O$-proportion of oxic species, $D$-proportion of dysoxic species.

Kaiho (1994) found no significant correlation between BFOI values and observed dissolved oxygen at stations where oxygen levels are above $3.5 \mathrm{ml} / \mathrm{l}$, whereas a good correlation existed where dissolved oxygen values are between 1.3 and $3.3 \mathrm{ml} / \mathrm{l}$. As the linear regression equation between BFOI values and dissolved oxygen values was not provided by Kaiho (1994, 1999), the calculated oxygen values were estimated by reading off oxygen values from Kaiho's (1994) x-y plot of BFOI values $v s$. dissolved oxygen $(\mathrm{ml} / \mathrm{l})$ with the help of a ruler. The relative proportions of benthic foraminiferal morphogroups in each sample, BFOI values, and calculated oxygen values are given in Appendix 2.

\section{RESULTS}

\section{WATER MASS PROPERTIES}

Our hydrographic survey results for dissolved oxygen $(\mathrm{ml} / \mathrm{l})$, salinity, and temperature $\left({ }^{\circ} \mathrm{C}\right)$ plotted against depth across the transect were reported by Phipps et al. (2010) and are replotted in Figure 3. Along the transect five distinct hydrographical zones can be identified in vertical profile:

1. Surface water. The surface layer to a depth of $\sim 15 \mathrm{~m}$ represents a homogeneous, brackish (salinity $=22.6-22.8$ ),
$\mathrm{T}$ a b l e 1

warm, low-density water mass with oxygen values between 3 and $4 \mathrm{ml} / \mathrm{l}$. The properties of this surface water are indicative of outflow water of Black Sea origin.

2. Pycnocline water. This zone ranges from $15 \mathrm{~m}$ to $25 \mathrm{~m}$, and represents the pycnocline where temperature drops rapidly from 25.8 to $19.8^{\circ} \mathrm{C}$, and salinity rises rapidly from 22.8 to 37.9 . Small patchy maxima in dissolved oxygen values are observed here with values locally in excess of $5 \mathrm{ml} / \mathrm{l}$, corresponding with the summer subsurface chlorophyll maximum. The higher dissolved oxygen values measured here can be attributed to seasonal photosynthetic activity. Along our transect, sea-floor dissolved oxygen values reach $4.3 \mathrm{ml} / \mathrm{l}$. Between $25 \mathrm{~m}$ and $30 \mathrm{~m}$ the dissolved oxygen content decreases again below the pycnocline. It is likely that this drop in values is due to reduced mixing beneath the brackish surface water.
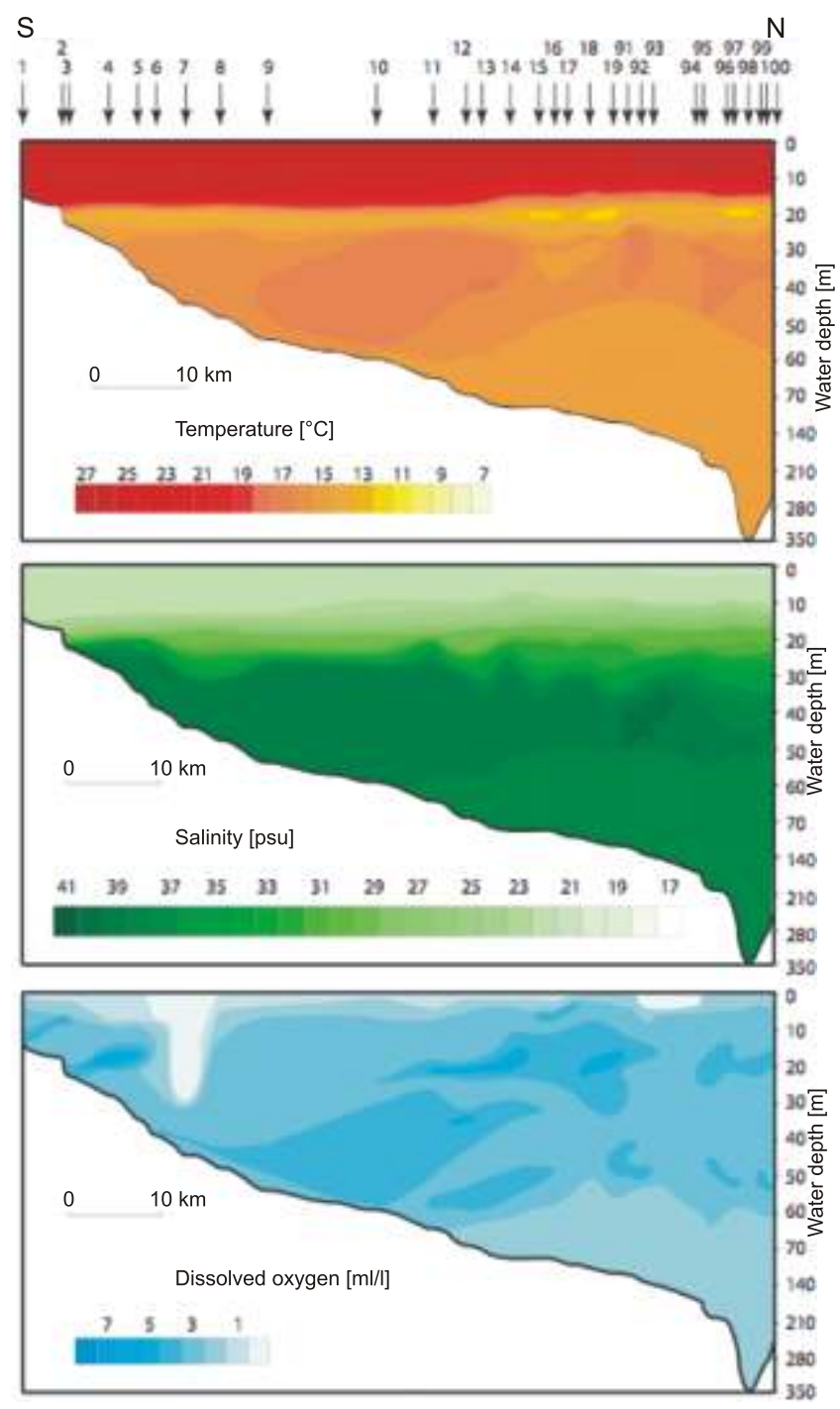

Fig. 3. Vertical profiles of temperature, salinity and dissolved oxygen sampled at $1 \mathrm{~m}$ depth intervals along the transect in summer 2002

Numbered arrows point to the locations of vertical T-S-O profiles and sea-floor grab samples 
3. Mediterranean inflow water. This depth zone is characterised by a rise in dissolved oxygen levels, with a peak value of $4.09 \mathrm{ml} / \mathrm{l}$ at $50 \mathrm{~m}$. A similar pattern is evident in the temperature and salinity values. This zone represents the summer inflow of the warm, saline Mediterranean countercurrent that originates in the Dardanelles Strait, turning to a southeasterly direction into Erdek Bay.

4. Upper Marmara Sea deep-water. This water mass is found from 60 to $300 \mathrm{~m}$ depth, and is characterized by stable salinity conditions (38.6-38.8), and a gradual decline in temperature $\left(16.2-14.4^{\circ} \mathrm{C}\right)$ and dissolved oxygen values (3.79-1.09 ml/l).

5. Lower Marmara Sea deep-water. This water mass shares the same temperature and salinity trends as Zone 4, but dissolved oxygen values show a small increase from $1.09 \mathrm{ml} / \mathrm{l}$ at $300 \mathrm{~m}$ to $1.42 \mathrm{ml} / \mathrm{l}$ at $325 \mathrm{~m}$. This rise in oxygen values is evidence of an undercurrent of Mediterranean origin that flows down the submarine canyon to the deeper part of the transect beneath the Marmara Ship Channel. The winter inflow of MIW is cooler and therefore denser, and this inflow ventilates the deeper portion of the Marmara Sea.

\section{THE BFOI}

A total of 211 calcareous benthic foraminiferal taxa belonging to 67 genera were identified in the samples (Phipps et al., 2010). Among them, 32 taxa show a relative abundance higher than $5 \%$ in at least one sample.

The calculated BFOI values in the transect range from a low of 1.50 at $65 \mathrm{~m}$, to 98.25 at $18 \mathrm{~m}$. The calculated oxygen values based on the BFOI are plotted in Figure 4, alongside the dissolved oxygen values measured at $1 \mathrm{~m}$ above sea-floor at each station. Although in the complete data set the correlation between measured and calculated dissolved oxygen values is weak (Pearson's $r=0.40$ ), deviations may be explained by seasonal changes in the hydrography at certain depths in the transect. Along the transect four depth-related zones can be identified that are related to the water-mass structure. These zones are characterized as follows:

1. Surface water (15 to $30 \mathrm{~m}$ depth). The shallowest part of the transect is influenced by brackish Marmara Sea surface water to the depth of the pycnocline and chlorophyll maximum. Here, the observed and calculated oxygen show strikingly similar values.

2. Mediterranean Inflow Water (30 to $75 \mathrm{~m}$ depth). This zone represents the inflow of the summer Mediterranean countercurrent, visible in the patch of subsurface high salinity values in Figure 3. Here there is a departure between the measured and calculated dissolved oxygen values. The calculated oxygen based on the BFOI displays lower values than the measured summer oxygen values in this part of the transect - this could be due to seasonal variations in the depth and location of the MIW, with a less dense inflowing current causing locally elevated oxygen values in the summer compared with winter conditions.

3. Upper Marmara Sea deep-water (75 to $140 \mathrm{~m}$ ). This part of the transect represents stable hydrographic conditions found below the summer MIW layer. Dissolved oxygen values

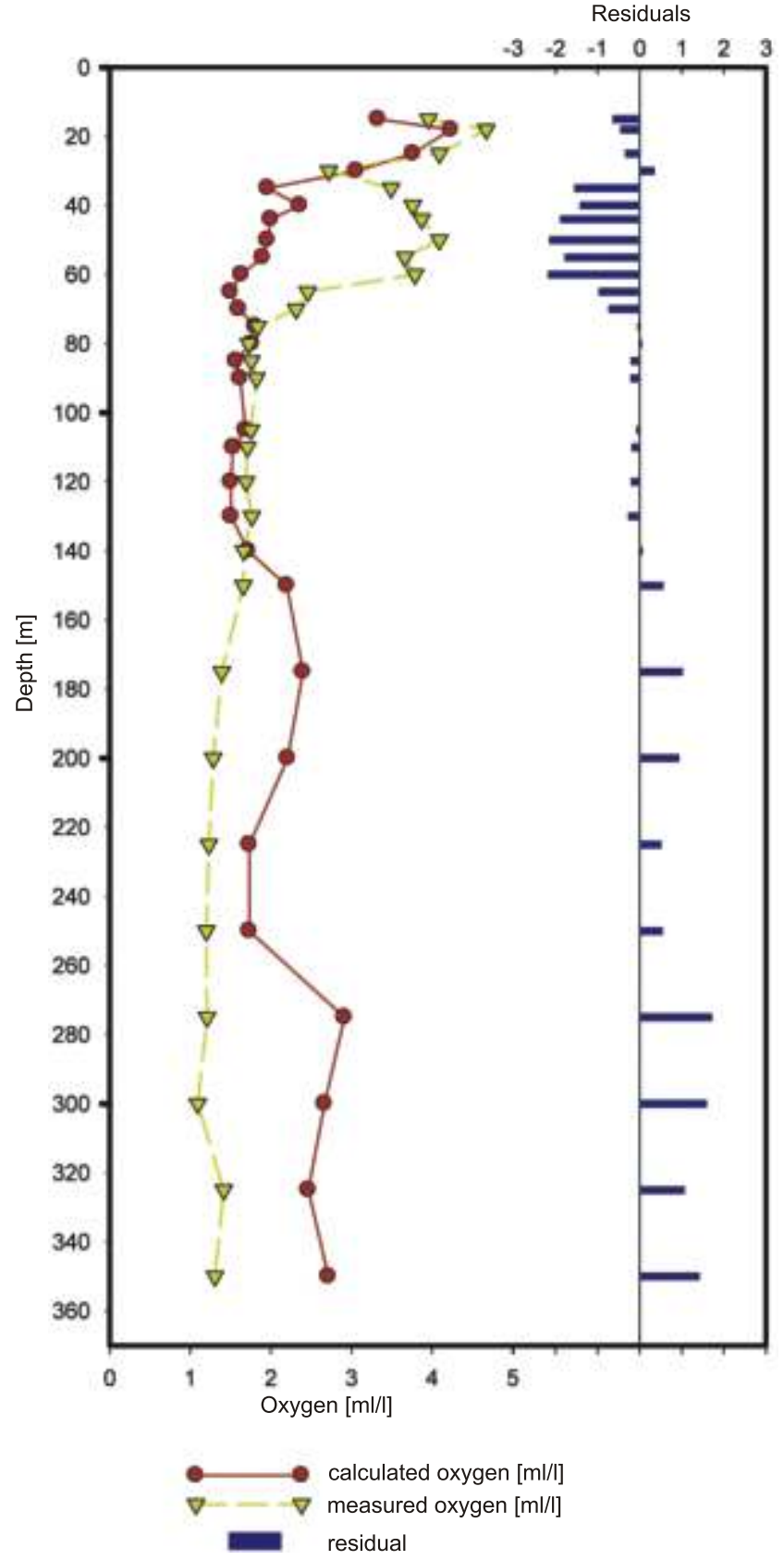

Fig. 4. Comparison between dissolved oxygen values measured at $1 \mathbf{~ m}$ above sea-floor and analogue oxygen values calculated from the BFOI

Also shown are the residuals. Negative residues in the Mediterranean Inflow Water indicate that the BFOI underestimates the measured oxygen, while positive residuals in the Marmara Sea deep-water indicate that the BFOI overestimates the measured oxygen

in this zone are well within the useful range for assessing the validity of Kaiho's BFOI. Here, the observed and calculated dissolved oxygen values coincide surprisingly well, with some values showing only $0.03 \mathrm{ml} / \mathrm{l}$ difference. There is no significant difference between the means of the observed and calculated oxygen values in this part of the transect as determined by Student's paired t-test $(\mathrm{n}=9, \mathrm{p}=0.13)$.

4. Lower Marmara Sea deep-water (140 to $350 \mathrm{~m}$ ). The transect below $140 \mathrm{~m}$ again shows a departure between calcu- 
lated and observed oxygen values, with two peaks in calculated oxygen values that are significantly higher than the observed oxygen values. The difference between the means is significant at a $99 \%$ confidence level as determined by Student's paired t-test $(\mathrm{n}=9, \mathrm{p}=0.0001)$. These peaks do not match any summer hydrographical evidence for a well-oxygenated inflow at these depths. However, the rise in BFOI values does coincide with a peak in $\%$ fragmentation and in diversity as measured by the Fisher $\alpha$-index (Phipps et al., 2010). Also, some of the sea-floor samples in the deep part of the transect contained visibly more sand and gravel. This supports the idea of the presence of a well-oxygenated winter MIW bottom current that flows down the submarine canyon into the deep Marmara Sea (Nielson, 1912)

\section{DISCUSSION}

The BFOI is by now a well-established proxy for dissolved oxygen content of bottom waters, and has been used by various workers to interpret changes in oxygenation as far back as the Cenomanian (Kaiho et al., 1993). In the Romanian Carpathians, Cetean et al. (2011) used the BFOI to interpret changes in oxygenation across the Santonian-Campanian boundary interval, while in the western Mediterranean area Alegret et al. (2003) used the index to assess environmental changes across the Cretaceous-Paleogene boundary in the Agost section in southern Spain. Drinia et al. (2003) used the index to interpret the oxygenation of upper Miocene sediments on Gavdos Island, Greece. Morigi (2009) calculated the BFOI values across the Quaternary sapropel S5 layer and used the proxy to interpret trends in oxygenation in the eastern Mediterranean, while Drinia and Anastasakis (2012) used the BFOI to interpret the Holocene history of oxygenation in the North Evoikos Gulf, Greece, a landlocked, semi-enclosed marine basin that is connected to the Aegean Sea through a narrow strait. However, the actual calibration of the BFOI in the modern ocean, and especially in the Atlantic-Mediterranean sector, is based on rather sparse data. The calibration of the BFOI to measured oxygen levels was originally carried out in the Pacific Ocean (Kaiho, 1994), were large areas of the continental margins are subjected to suboxic or dysoxic conditions. With notable exceptions, most parts of the Atlantic Ocean and Mediterranean have dissolved oxygen contents $>3 \mathrm{ml} / \mathrm{l}$, and are within range of values that show a very weak correlation to the BFOI proxy in Kaiho's study. Indeed, a number of researchers working on benthic foraminifera from Mediterranean sapropels avoid the use of the index altogether (e.g., Schmiedl et al., 2003; Abu-Zied et al., 2008), and instead emphasise the role of trophic gradients and carbon flux in structuring benthic communities (e.g., Jorissen et al., 2007). However, those who are of the opinion that benthic foraminiferal assemblages are entirely controlled by trophic gradients would need to explain why there is any correlation at all between the proportions of foraminiferal morphogroups used to calculate the BFOI and the dissolved oxygen content in bottom waters.

The Marmara Sea is a dysoxic basin with dissolved oxygen values as low as $1 \mathrm{ml} / \mathrm{l}$ in the deeper eastern parts of the basin (Alavi, 1988). Therefore, I assumed that the BFOI proxy should be of potential utility for interpreting the history of bottom water ventilation in the Marmara Sea. Aksu et al. (2002a) calculated BFOI values in samples collected from a piston core from the southern Marmara Shelf and showed that the Holocene values of the index have been fairly constant since the reflooding of the sea following the last deglaciation. In this piston core collected at $111 \mathrm{~m}$ depth on the southern Marmara Shelf the core-top BFOI value faithfully reproduced the modern sea-floor dissolved oxygen value measured at the same locality, which strongly suggested the proxy could be used to interpret the Holocene history of the Marmara Sea. However, at the time Aksu et al. (2002) interpreted the benthic foraminiferal record from this core in terms of the BFOI proxy, there were no published studies of modern foraminifera that directly calibrated the BFOI values to measured modern dissolved oxygen contents in the Mediterranean or its marginal seas. The current study was therefore undertaken with the aim of providing calibrations between hydrographic parameters and this micropalaeontological proxy.

The correlation between BFOI and $\mathrm{O}_{2}$ values measured in the summer of 2002 can be seen in Figure 4. The three shallow stations $(15,18$ and $25 \mathrm{~m})$ are under the influence of brackish surface waters, which are well-oxygenated, and the BFOI values almost exactly reproduce the measured $\mathrm{O}_{2}$ values. However, at deeper stations on the Marmara shelf (between 30 and $75 \mathrm{~m}$ ) the BFOI underestimates the dissolved oxygen values as observed in the summer of 2002. In the summer months a subsurface chlorophyll maximum is present, and consequently dissolved oxygen values are expected to be higher than in winter. This anomaly disappears at $75 \mathrm{~m}$ depth, and the BFOI and measured $\mathrm{O}_{2}$ values correlate very well on the outer shelf of the southwestern Marmara Shelf.

Below $150 \mathrm{~m}$ depth in the Marmara Ship Channel, the BFOI overestimates the summer $\mathrm{O}_{2}$ values. The faunal proportions in the foraminiferal samples and higher species diversity values observed at 300-350 m depth suggest that a more well-oxygenated water mass ought to be present at the deeper stations (Phipps et al., 2010; Frontalini et al., 2011). Cibicides advenum, for example, is a species placed in the oxic morphogroup that lives attached to the substrate, and its elevated proportions (around 7\%) here is likely related to the presence of coarser substrate (recovered sediment at some of the deeper stations contained visibly coarse sediment, including pebbles) and a well-oxygenated water mass. In winter, the MIW is cooler and denser, and cascades down the submarine canyon beneath the Marmara Ship Channel, ventilating the deeper water mass of the Marmara Sea. The Danish Oceanographical Expedition of 1908-1910 first identified a denser "winter water" of Mediterranean origin in the deep basin of the Marmara Sea, and a relatively lighter "summer water" mass of Mediterranean origin that flows in at shallower levels during the summer months (Nielson, 1912). Dissolved oxygen concentrations in the deeper layer were shown to be higher than at stations within the summer water mass. In our data set the small increase in oxygen values at the two deepest stations (325-350 m) provides evidence of this lingering winter undercurrent of Mediterranean origin. However, we have no winter $\mathrm{T}-\mathrm{S}-\mathrm{O}$ profiles collected along the transect to corroborate these 
observations, and the correlation between the BFOI and winter $\mathrm{O}_{2}$ values remains to be tested.

\section{CONCLUSIONS}

1. Kaiho's BFOI can accurately reproduce the measured dissolved oxygen values in the Marmara Sea, thereby expanding the potential usefulness of the method to the Mediterranean area. On the outer shelf of the Marmara Sea there is essentially no difference between the observed $\mathrm{O}_{2}$ values measured $1 \mathrm{~m}$ above the sea-floor and the analogue oxygen values calculated from the BFOI proxy.

2. The discrepancies between calculated and measured dissolved oxygen values can be explained by the complex oceanography of the southwestern Marmara Sea in the proximity of the Dardanelles Strait. At deeper stations beneath the Marmara Ship Channel, a winter bottom current of Mediterranean origin may be responsible for the elevated BFOI values compared with $\mathrm{O}_{2}$ values observed in summer. During the summer the MIW occupies an intermediate depth, turning towards the south-east over the southern Marmara Shelf, while the winter inflow is denser and cascades down the submarine canyon be- neath the Marmara Ship Channel, ventilating the deeper waters of the Marmara Basin. It is likely that the BFOI based upon dead foraminiferal assemblages collected from surface sediment reflects the multi-annual average of dissolved oxygen values in the area. Consequently, a comparison of the BFOI with the summer $\mathrm{O}_{2}$ values measured at the time of sampling highlights the seasonal variations in the local hydrography of the southwestern Marmara Sea.

Acknowledgements. I wish to thank the scientific party of the MAR-02 Cruise for the opportunity to take part in the expedition and collect samples. R. Hiscott, A. Aksu (Memorial University Newfoundland), and the Captain and crew of the R/V Koca Piri Reis for are especially thanked for their logistical support. I gratefully acknowledge the diligent work done by C. Chendes (Babeş-Bolyai University) in the task of processing and picking the transect samples, and by M. Phipps (Petrostrat, Llandudno) in recording the species abundances as part of an NERC advanced course studentship in Micropalaeontology at UCL. A. Gooday (Southampton) and C. Morigi (Copenhagen) kindly offered their comments on an early draft of the manuscript. C. Cetean (Fugro, Llandudno) and an anonymous reviewer read the final manuscript.

\section{REFERENCES}

ABU-ZIED R.H., ROHLING E.J., JORISSEN F.J., FONTANIER C., CASFORD J.S.L. and COOKE S. (2008) - Benthic foraminiferal response to changes in bottom-water oxygenation and organic carbon flux in the eastern Mediterranean during LGM to Recent times. Mar Micropaleont., 67 (1-2): 46-68.

AKSU A.E., CALON T.J., HISCOTT R.N. and YAŞAR D. (2000) - Anatomy of the North Anatolian Fault Zone in the Marmara Sea, western Turkey: extensional basins above a continental transform. GSA Today, 10: $3-7$.

AKSU A.E., HISCOTT R.N., KAMINSKI M.A., MUDIE P.J., GILLESPIE H., ABRAJANO T. and YAŞAR D. (2002a) - Last Glacial to Holocene paleoceanography of the Black Sea and Marmara Sea: Stable isotopic, foraminiferal and coccolith evidence. Mar. Geol., 190: 119-149.

AKSU A.E., HISCOTT R.N., MUDIE P.J., ROCHON A., KAMINSK M.A., ABRAJANO T. and YASAR D. (2002b) - Persistent Holocene outflow from the Black Sea to the Eastern Mediterranean contradicts Noah's Flood Hypothesis. GSA Today, 12 (5): 4-10.

ALAVI S.N. (1988) - Late Holocene deep-sea benthic foraminifera from the Sea of Marmara. Mar. Micropalaeont., 13: 213-237.

ALEGRET L., MOLINA E. and THOMAS E. (2003) - Benthic foraminiferal turnover across the Cretaceous/Paleogene boundary at Agost (southeastern Spain): paleoenvironmental inferences. Mar. Micropaleont., 48: 251-279.

AVŞAR N., AKSU A. and DINCER F. (2006) - Benthic foraminiferal assemblages of the Erdek Bay (SW Marmara Sea) (in Turkish with English summary). Yerbilimleri [Journal of the Earth Sciences Application and Research Center of Hacettepe University], 27 (3): 125-141.

CETEAN C., BĂLC R., KAMINSKI M.A. and FILIPESCU S. (2011) - Integrated biostratigraphy and palaeoenvironments of an upper Santonian - upper Campanian succession from the southern part of the Eastern Carpathians, Romania. Cret. Res., 32: 575-590.

CHENDES C., KAMINSKI M.A., FILIPESCU S., AKSU A.E. an YAŞAR D. (2004) - The response of modern benthic foraminiferal assemblages to water-mass properties along the southern shelf of the Marmara Sea. Acta Palaeont. Romaniae, 4: 69-80.
CIMERMAN F. and LANGER M.R. (1991) - Mediterranean Foraminifera. Slovenska Akademija Znanosti in Umetnosti, Ljubljana.

DRINIA H. and ANASTASAKIS G. (2012) - Benthic foraminifer palaeoecology of the Late Quaternary continental outer shelf of a landlocked marine basin in central Aegean Sea, Greece. Quatern. Intern., 261: $43-52$.

DRINIA H., TSAPARAS N., ANTONARAKOU A. and GOUMAS G. (2003) - Benthic foraminiferal biofacies associated with middle to early late Miocene oxygen deficient conditions in the eastern Mediterranean. Eighth International Conference on Environmental Science and Technology, Lemnos Island, Greece, 8-10 September, 2003. Abstracts and Program.

ERGIN M., KAZANCI N., VAROL B., ILERI O. and KARADENIZLI L. (1997) - Sea-level changes and related depositional environments on the southern Marmara shelf. Mar. Geol., 140: 391-403.

FRONTALINI F., KAMINSKI M.A., COCCIONI R., BUCCI C. and AKSU A.E. (2011) - Paleobathymetric distribution and ecology of agglutinated foraminifera along an inner neritic to upper bathyal transect in the Marmara Sea. Grzybowski Found. Spec. Publ., 16: 37-52.

JORISSEN F.J., FONTANIER C. and THOMAS E. (2007) Paleoceanographical proxies based on deepsea benthic foraminiferal assemblage characteristics. In: Proxies in Late Cenozoic paleoceanography (eds. C. Hillaire-Marcel and A. de Vernal): 263-313. Elsevier.

KAIHO K. (1991) - Global changes of Paleogene aerobic/anaerobic benthic foraminifera and deep-sea circulation. Palaeogeogr. Palaeoclimatol. Palaeoecol., 83: 65-85.

KAIHO K. (1994) - Benthic foraminiferal dissolved-oxygen index and dissolved-oxygen levels in the modern ocean. Geology, 22: 719-722.

KAIHO K. (1999) - Effect of organic carbon flux and dissolved oxygen on the benthic foraminiferal oxygen index (BFOI). Mar. Micropalaeont., 37: 67-76.

KAIHO K., FUJIWARA O. and MOTOYAMA I. (1993) - Mid-Cretaceous faunal turnover of intermediate-water benthic foraminifera in the 
northwestern Pacific Ocean margin. Mar. Micropaleont., 23 (1): $13-49$.

KAMINSKI M.A., AKSU A.E., BOX M., HISCOTT R.N., FILIPESCU S. and Al-SALAMEEN M. (2002) - Late Glacial to Holocene benthic foraminifera in the Marmara Sea: implications for Black Sea - Mediterranean Sea connections following the last deglaciation. Mar. Geol., 190: $165-202$.

MORIGI C. (2009) - Benthic environmental changes in the Eastern Mediterranean Sea during sapropel S5 deposition. Palaeogeogr. Palaeoclimatol. Palaeoecol., 273: 258-271.

NIELSON J.N. (1912) - Hydrography of the Mediterranean and adjacent waters. In: Report on the Danish Oceanographical Expedition 1908-1910 to the Mediterranean and adjacent waters, 1: 77-191. Copenhagen.

PARKER F.L. (1958) - Eastern Mediterranean foraminifera. Sediment cores from the Mediterranean and Red Sea. Report of the Swedish Deep Sea Expedition, 8: 219-283.
PHIPPS M., KAMINSKI M.A. and AKSU A.E. (2010) - Calcareous benthic foraminiferal biofacies on the southern Marmara Shelf. Micropaleontology, 56 (3-4): 377-392.

RASMUSSEN T.L. (2005) - Systematic paleontology and ecology of benthic foraminifera from the Plio-Pleistocene Kallithea Bay section, Rhodes, Greece. Cushman Found. Spec. Publ., 39: 53-157.

SGARRELLA F. and MONCHARMONT ZEI M. (1993) - Benthic foraminifera of the Gulf of Naples (Italy): Systematics and autoecology. Boll. Soc. Paleont. Ital., 32: 145-264.

SCHMIEDL G., MITSCHELE A., BECK S., EMEIS K-C., HEMLEBEN C., SCHULZ H., SPERLING M. and WELDEAB S. (2003) - Benthic foraminiferal record of ecosystem variability in the eastern Mediterranean Sea during times of sapropel S5 and S6 deposition. Palaeogeogr. Palaeoclimatol. Palaeoecol., 190: 139-164.

YANKO V.V. and TROITSKAYA T.S. (1987) - Late Quaternary Foraminifera of the Black Sea (in Russian). Trudy Inst. Geol. Geofiz., Akad. Nauk SSSR, Novosibirsk, 694.

\section{APPENDIX 1}

\section{List of taxa found in the Marmara Sea transect, grouped according to the oxygen-related faunal groups of Kaiho (1994). The full taxon names and faunal abundance data were given by Phipps et al. (2010)}

Oxic indicators $(\geq 350 \mathrm{~m}$, thick walled epifauna in high oxygen $\left[>2 \mathrm{ml} / 1 \mathrm{O}_{2}\right]$ bottom water) consist of: Adelosina carinata-striata, Adelosina italica, Adelosina pulchella, Adelosina longirostra, Ammonia beccarii forma beccarii, Ammonia beccarii forma inflata, Ammonia parkinsoniana, Ammonia tepida, Ammonia sp. 1 and 2 (Cimerman and Langer). Ammonia spp., Asterigerinata mamilla, Biloculinella depressa, Biloculinella globula, Biloculinella labiata, Biloculinella wiesneri, Buccella granulata, Challengerella bradyi, Cibicidella variabilis, Cibicides advenum, Cibicides dutemplei, Cibicides lobatulus, Cibicides refulgens, Cibicides ungerianus forma pseudoungerianus, Cibicides spp., Cornuspira foliacea, Cornuspira involvens, Cycloforina contorta, Cycloforina rugosa, Cycloforina tenuicollis, Discorbinella bertheloti, Elphidium advenum forma maorim (biconvex, thick walled), Elphidium crispum group (biconvex, thick walled), Elphidium punctatum (biconvex, thick walled), Gavelinopsis praegeri, Globocassidulina oblonga, Globocassidulina subglobosa, Miliolinella elongata, Miliolinella dilatata, Miliolinella labiosa, Miliolinella subrotunda, Neoconorbina terquemi, Opthalmidium acutimargo, Pygro anomala, Pygro elongata, Pygro inornata, Planorbulina mediterranensis, Pseudoeponides falsobeccarii, Pseudotriloculina laevigata, Quinqueloculina berthelotiana, Quinqueloculina bidentata, Quinqueloculina bosciana, Quinqueloculina disparilis, Quinqueloculina laevigata, Quinqueloculina milletti, Quinqueloculina padana, Quinqueloculina pygmaea, Quinqueloculina seminula, Quinqueloculina stalkeri, Quinqueloculina undulata, Quinqueloculina spp, Sigmoilinita costata, Sigmoilinita sigmoidea, Sigmoilinita tenuis, Sigmoilinita sp. 1 (Cimerman and Langer), Sigmoilinita cyumbium, Sigmoilopsis schlumbergeri, Sigmoilopsis sp., Spiroloculina communis, Spiroloculina depressa, Spiroloculina excavata, Spiroloculina tenuiseptata, Triloculina gibba, Triloculina plicata, Triloculina schreiberiana and Triloculina tricarinata.

Suboxic indicators B include: Amphicoryna hispida, Amphicoryna intercellularis, Amphicoryna proxima, Amphi- coryna scalaris, Asterigerinata adriatica (small, thin walled and ornamented with pustules), Bulimina costata, Bulimina denudata, Bulimina marginata, Bulimina pagoda, Cassidulina obtusa, Dentalina albatrossi, Dentalina communis, Dentalina guttifera, Dentalina inflexa, Dentalina inornata, Dentalina leguminiformis, Dentalina mucronata, Dentalina sp. 1, Elphidium complanatum, Elphidium complanatum forma tyrrhenianum, Elphidium granosum forma granosum, Elphidium granosum forma lidoense, Elphidium incertum, Elphidium magellanicum, Elphidium margaritaceum, Elphidium poeyanum forma decipiens, Elphidium poeyanum forma poeyanum, Elphidium reginum, Elphidium sp. A (Sgarrella and Moncharmont Zei), Elphidium sp. 4 (Cimerman and Langer), Elphidium sp. 1, Epistominella vitrea, Fissurina castanea, Fissurina faba, Fissurina lucida, Fissurina neptunii, Fissurina orbignyana, Fissurina spp., Glandulina laevigata, Guttulina lactea, Gyroidina umbonata, Haynesina depressula, Haynesina spp., Hyalinea baltica (flattened, thin wall, very low trochospiral), Lagena doveyensis, Lagena gracillima, Lagena laevis, Lagena striata, Lagena semistriata, Lagena substriata,, Lagena sp. 2 (Cimerman and Langer), Lagena sp., Lenticulina cultrata, Lenticulina gibba, Lenticulina peregrina, Melonis barleanum, Neoconorbina sp. (thin wall, small), Neolenticulina peregrina, Oolina acuticostata, Oolina hexagona, Oolina melo, Parafissurina staphyllearia, Parafissurina sp, Parrellina verriculata, Patellina corrugata (thin wall, small test), Pullenia quinqueloba, Reussella spinulosa, Robertina translucens, Rosalina floridensis, Rosalina globularis, Rosalina bradyi, Rosalina obtusa, Sigmomorphina williamsoni, Siphonina reticulate, Sphaeroidina bulloides, Spirillina vivipara, Stainforthia complanata, Stainforthia sp. (Rasmussen), Stainforthia sp. 1, Trifarina angulosa, Trifarina fornasinii, Uvigerina mediterranea, Uvigerina peregrina, Vaginulina lequilensis, Valvulineria complanata, Valvulineria perlucida and Valvulineria sp.

Suboxic indicators $\mathbf{C}$ (thin walled and found in intermediate habitats between those of intermediate indices B and 
dysoxic indices) are: Bulimina aculeata, Bulimina elongata, Elphidium excavatum, Nonionella stella, Nonionella turgida group, and Nonionella spp.

Dysoxic indicators (thin walled, elongate, flattened infauna, including Astacolus crepidulus, Bolivina aenariensis,
Bolivina pseudopunctata, Bolivina striata, Bolivina variabilis, Bolivina sp 1, Brizalina alata, Brizalina catanensis, Brizalina dilatata, Brizalina spathulata, Cassidulina carinata (thin wall, high porosity), Chilostomella mediterranensis, Fursenkoina acuta, Globobulimina affinis and Globobulimina turgida.

\section{APPENDIX 2}

Benthic foraminiferal morphogroup data for each station, with BFOI and corresponding calculated oxygen values. Also given are dissolved oxygen, temperature and salinity values measured $1 \mathrm{~m}$ above the sea-floor

\begin{tabular}{|c|c|c|c|c|c|c|c|c|c|c|c|}
\hline \multirow[b]{2}{*}{$\begin{array}{c}\text { Depth } \\
{[\mathrm{m}]}\end{array}$} & \multicolumn{11}{|c|}{ Station } \\
\hline & $\begin{array}{c}\text { Oxic } \\
\text { indicators }\end{array}$ & $\begin{array}{c}\text { Suboxic } \\
\text { indicators } \\
\text { A }\end{array}$ & $\begin{array}{c}\text { Suboxic } \\
\text { indicators } \\
\text { B }\end{array}$ & $\begin{array}{c}\text { Suboxic } \\
\text { indicators } \\
\text { C }\end{array}$ & $\begin{array}{l}\text { Dysoxic } \\
\text { indicators }\end{array}$ & $\begin{array}{l}\text { Total } \\
\text { count }\end{array}$ & $\begin{array}{l}\text { BFOI } \\
\text { index }\end{array}$ & $\begin{array}{c}\text { Calculated } \\
\text { oxygen } \\
{[\mathrm{ml} / \mathrm{l}]}\end{array}$ & $\begin{array}{c}\text { Measured } \\
\text { oxygen } \\
{[\mathrm{ml} / 1]}\end{array}$ & $\begin{array}{c}\text { Temperature } \\
{\left[{ }^{\circ} \mathrm{C}\right]}\end{array}$ & Salinity \\
\hline 15 & 21 & 259 & 122 & 23 & 11 & 436 & 65.625 & 3.33 & 3.95676 & 25.8232 & 22.8391 \\
\hline 18 & 201 & 303 & 399 & 2 & 4 & 909 & 98.049 & 4.233 & 4.67302 & 19.8253 & 24.8995 \\
\hline 25 & 78 & 127 & 597 & 123 & 16 & 941 & 82.979 & 3.763 & 4.09182 & 15.1406 & 37.9022 \\
\hline 30 & 30 & 141 & 154 & 29 & 24 & 378 & 55.556 & 3.06 & 2.7196 & 15.6536 & 37.8971 \\
\hline 35 & 10 & 84 & 173 & 60 & 53 & 380 & 15.873 & 1.959 & 3.49211 & 16.1062 & 38.4855 \\
\hline 40 & 53 & 442 & 372 & 76 & 119 & 1062 & 30.814 & 2.3599 & 3.76083 & 16.3836 & 38.7062 \\
\hline 44 & 27 & 123 & 247 & 77 & 129 & 603 & 17.308 & 2 & 3.87113 & 16.4892 & 38.8305 \\
\hline 50 & 19 & 206 & 157 & 50 & 102 & 534 & 15.702 & 1.955 & 4.09095 & 16.6828 & 38.929 \\
\hline 55 & 38 & 137 & 186 & 97 & 246 & 704 & 13.380 & 1.899 & 3.66438 & 16.2749 & 38.8948 \\
\hline 60 & 10 & 118 & 122 & 52 & 212 & 514 & 4.505 & 1.633 & 3.78869 & 16.2492 & 38.9712 \\
\hline 65 & 6 & 85 & 175 & 52 & 394 & 712 & 1.5 & 1.5 & 2.45641 & 15.6475 & 38.8539 \\
\hline 70 & 12 & 71 & 150 & 55 & 275 & 563 & 4.181 & 1.599 & 2.31581 & 15.3651 & 38.7896 \\
\hline 75 & 31 & 77 & 202 & 92 & 301 & 703 & 9.337 & 1.806 & 1.83615 & 14.9967 & 38.7141 \\
\hline 80 & 52 & 208 & 557 & 224 & 534 & 1575 & 8.874 & 1.7599 & 1.72662 & 14.8452 & 38.6777 \\
\hline 85 & 21 & 141 & 444 & 89 & 699 & 1394 & 2.917 & 1.566 & 1.75689 & 14.8782 & 38.6815 \\
\hline 90 & 15 & 79 & 293 & 62 & 298 & 747 & 4.792 & 1.6199 & 1.82184 & 14.8834 & 38.6844 \\
\hline 105 & 28 & 113 & 475 & 83 & 463 & 1162 & 5.703 & 1.6866 & 1.75246 & 14.8923 & 38.6794 \\
\hline 110 & 16 & 83 & 193 & 45 & 541 & 878 & 2.873 & 1.533 & 1.70836 & 14.8248 & 38.6773 \\
\hline 120 & 3 & 27 & 103 & 22 & 192 & 347 & 1.538 & 1.503 & 1.69278 & 14.8256 & 38.6677 \\
\hline 130 & 8 & 50 & 152 & 16 & 384 & 610 & 2.041 & 1.5066 & 1.76458 & 14.8832 & 38.6865 \\
\hline 140 & 18 & 24 & 164 & 18 & 254 & 478 & 6.618 & 1.7166 & 1.66361 & 14.6351 & 38.6517 \\
\hline 150 & 39 & 31 & 116 & 13 & 117 & 316 & 25 & 2.199 & 1.65802 & 14.6243 & 38.6505 \\
\hline 175 & 72 & 68 & 245 & 41 & 149 & 575 & 32.579 & 2.399 & 1.39261 & 14.4731 & 38.6621 \\
\hline 200 & 88 & 85 & 317 & 26 & 247 & 763 & 26.268 & 2.21 & 1.28655 & 14.46 & 38.6629 \\
\hline 225 & 38 & 64 & 343 & 29 & 514 & 988 & 6.884 & 1.733 & 1.23159 & 14.4456 & 38.6641 \\
\hline 250 & 23 & 61 & 214 & 20 & 311 & 629 & 6.886 & 1.733 & 1.20106 & 14.4397 & 38.6654 \\
\hline 275 & 64 & 30 & 98 & 8 & 55 & 255 & 53.782 & 2.913 & 1.20914 & 14.4519 & 38.6636 \\
\hline 300 & 58 & 44 & 122 & 14 & 79 & 317 & 42.336 & 2.666 & 1.09373 & 14.4194 & 38.666 \\
\hline 325 & 43 & 23 & 100 & 8 & 74 & 248 & 36.752 & 2.466 & 1.41561 & 14.4091 & 38.6654 \\
\hline 350 & 75 & 59 & 140 & 14 & 96 & 384 & 43.859 & 2.7133 & 1.30699 & 14.4019 & 38.6657 \\
\hline
\end{tabular}

